\title{
Boska władza reżysera. Karel Hugo Hilar - pierwszy nowoczesny reżyser w czeskim teatrze*
}

\begin{abstract}
Czachór Sylwia, Boska władza reżysera. Karel Hugo Hilar - pierwszy nowoczesny reżyser w czeskim teatrze (The Divinity of Director's Power. Karel Hugo Hilar - the First Modern Czech Theatre Director). „Poznańskie Studia Slawistyczne” 5. Poznań 2013. Adam Mickiewicz University Press, pp. 75-87. ISBN 978-83-232-2636-9. ISSN 2084-3011.

The aim of this research was to characterize changes in the perception of a function of theatre director at the begging of the 20th century. The Czech theatrical culture taking the pattern of great European theatre reformers of that time, created a genuine theatrical theory of directing. Its first representative and implementer was Karel Hugo Hilar. His work was based on an assumption that a director is the highest instance in a preparation of performance, that can be compared only to a role of a sovereign. Moreover, Hilar was the first in the Czech cultural context to call a director the creator of a scenic reality. A reality that would represent a current world view transformed by theatrical means and the creative imagination of an artist.
\end{abstract}

Keywords: 20th Century Czech Theatre; Hilar; Reinhardt; Craig; theatre directing theory; scenic reality

Nebot' režisérství je pocit stvoritelský, je to budování vlastního světa k svému obrazu... Jiří Frejka

Czeskie czasopismo teatralne „Divadlo” z początkowych lat XX wieku poświęcone jest $\mathrm{w}$ znacznej mierze sztuce aktorskiej. Pojawiają się w nim artykuły na temat historii i teorii czeskiej gry scenicznej czy wspa-

* Artykuł powstał podczas pobytu autorki w Pradze w roku akademickim 2012/2013. Stypendium sfinansowane zostało przez Międzynarodowy Fundusz Wyszehradzki. 
niałych występów aktorskich, dominują jednakże sylwetki poszczególnych artystów, których podobizny zdobią niemal każdą okładkę numerów wydawanych w latach 1902-1913. Do innych tematów poruszanych w czasopiśmie należą: historia czeskiego teatru, architektura teatralna czy teoria dramatu. Recenzje przybierające formę sprawozdań z niezapomnianych, bądź odwrotnie, nieudanych popisów aktorskich, najczęściej nie uwzględniają nazwiska reżysera, choć jednym z ocenianych elementów jest interpretacja dramatu. Należała ona jednak wówczas do domeny aktora-solisty, którego wiek XIX uczynił gwiazdą teatru, a pozostałe środki sceniczne miały jedynie stwarzać odpowiednią atmosferę, kreować iluzję przedstawianych zdarzeń. Podobnie artyści grający role drugo- i trzecioplanowe swoje interpretacje postaci podporządkowywali występowi solisty.

Mimo niemal zupełnej nieobecności nazwisk reżyserów na łamach czasopism, wyodrębniano $\mathrm{w}$ teatrze funkcję osoby odpowiedzialnej za całokształt przedstawienia. Sprawował ją jednak wówczas albo autor wystawianego dramatu, albo wybitny aktor, którego sława gwarantowała odpowiednie odczytanie dzieła literackiego. W tym celu opatrywano także nowe dramaty wskazówkami reżyserskimi i scenicznymi. Teatr miał bowiem za zadanie wystawić dzieło literackie zgodnie z jego duchem czy też zgodnie z intencją autora (Želenský 1908: 318).

$\mathrm{Z}$ czasem jednak funkcja reżysera stawała się coraz bardziej odpowiedzialna, a jego władza nad inscenizacją rozleglejsza. Od 1905 roku zaczęto prowadzić kurs dla przyszłych reżyserów, w którego programie znalazł się między innymi: „výklad o umění hereckém, o režii, právech a povinnostech režiséra nejen jako zástupce autora, ale i jako učitele a rádce všech učinkujících” („Divadlo” 1905: 423). W roli nauczyciela występował Karel Želenský - znany aktor Teatru Narodowego w Pradze, który po kilku latach występowania na scenie zaczął również pełnić funkcję reżysera. On także jako pierwszy na łamach czasopisma „Divadlo" sproblematyzował zagadnienie reżyserii. W jego artykule $O$ režisérství, ukazującym się w cześsciach w latach 1907-1908, pojawia się kilka interesujących i nowatorskich spostrzeżeń. Przede wszystkim Želenský uważa, że na reżyserze ciąży całkowita odpowiedzialność za powodzenie inscenizacji. Dlatego ten „výjimečný úřad” sprawować powinni jedynie „lidé bystrého pozorování, jemného vkusu uměleckého, vnímavé chápavosti, velkého vzdělání, silné vůle a neústupné energie" (Želenský 1907-1908: 4). Dzięki powyższym 
przymiotom reżyser może stać się autorytetem, który zbadawszy uprzednio dogłębnie dzieło literackie, służy aktorom radą oraz wydaje instrukcje dotyczące interpretacji dramatu. Pełni zatem funkcję nauczyciela, doradcy, przewodnika.

W artykule Želenskiego innowacyjne wydaje się nazwanie reżysera współtwórcą dzieła: „dovede pro své tvoření a krásný úřad svůj vyčísti z řádek spisovatelových tolik látky, barev, světla a duše" (Želenský 19071908: 65-66). Tym samym inscenizacja nie jest już jedynie odtworzeniem świata literackiego, ale także stwarzaniem własnej rzeczywistości (choć w niewielkim jeszcze zakresie). Co więcej, Želenský podkreśla, że spektakl powinien być naznaczony stylem reżysera artysty, po czym przekonuje:

Reřisér je umělec tvořivý, a tvořivost nesmí býti nijak a nikým obmezována, nemá-li se zvrátit v hudlařské řemeslnění, uspokojující pouze pánovitého zákaznika. (...) A nemyslíte, že jsou i režiséři, kteří tvoří? A tvoří-li, že každý prozrazuje ve svých režiích vlastní svoji individuálnost, osobitou ryzost své práce, svéráznost pochopení? A hlavně svéráznost pochopení! (...) Svéráznost tvoření režisérova přihlašuje se na jevišti zvláštním dojmem, jímž celek dýchá! A dojem tento je vždy protilehlý osobní povaze režisérově (Želenský 1907-1908: 115-116).

Wrażenie szczególnej jedności zapewnić może jednak tylko współpraca całego zespołu z reżyserem, który ,je souboru uměleckému jako vůdce armádě! Učí se omyly. Sám poučen může poučovat, a je-li poctivý - poučuje rád" (Želenský 1908: 318). Obdarzony niezwykłymi umiejętnościami reżyser nauczyciel potrafi nawet $\mathrm{z}$ aktora grającego epizodyczne role uczynić „gotowego artystę", ponieważ

zná prostředky, jakými probudit v tom či onom episodistovi způsobilost chápání, vlastním mozkem naučí myslit mozek jeho, vlastním teplem rozehřeje chlad jeho srdce, vlastní duší probudí duši svého svěřence. (...) K tomu cíli především však nutno, by režisér sám měl mozek, cit, duši a srdce! (Želenský 1907-1908: 66).

Nie dotyczy to jednak aktorów-solistów, którzy u Želenskiego nadal odgrywają zasadniczą rolę w budowaniu przedstawienia. Reżyser może im doradzać, ponieważ przestudiował dokładnie dzieło literackie i na tej podstawie pilnuje, aby całość nie była sprzeczna z charakterem dramatu, nie 
śmie jednak pokazywać aktorom, jak mają grać i w jaki sposób interpretować postaci. Swoje granice ma również wolność reżysera w kreowaniu indywidualnego stylu na scenie, musi być bowiem podporządkowany z jednej strony stylowi dramatu, z drugiej - prawdzie Natury. Dlatego między innymi Želenský przestrzega przed próbą narzucenia aktorom stylizowanego sposobu gry. W przeciwnym razie reżyser przestanie być specjalistą w swojej dziedzinie, a stanie się „divadelníkiem”: „Divadleník! Špinavé slovo, jež vedle «odborník» je stínem světla! «Divadelník» je název hrůzný, štítivý a oplzlý pro lidi čestné!" (Želenský 1908: 344). Twórczy duch reżysera w koncepcji Želenskiego ciągle zatem poddaje się dziewiętnastowiecznym ograniczeniom.

Większą wolność przynosi rok kolejny. W numerze 15. z 1909 roku, co ciekawe w rubryce „Herectvo”, pojawia się druga, znacznie krótsza rozprawa na temat zadań reżysera w nowoczesnym teatrze. Jej autorem jest Josef Lukavský, także aktor praskich scen. Uważa on, że problem rodzimej reżyserii pozostaje nierozwiązany, co prowadzi do tego, że czeskiego teatru nie można nazwać sztuką. Przyczyny takiego stanu upatruje w sposobie pracy reżyserów, którzy zajmują się jedynie aranżowaniem sceny, kostiumów i masek, zamiast skupić się na dążeniu do nadania inscenizacji oryginalnego stylu, jedności ducha i formy. Wysuwa zatem podobne postulaty do zawartych w artykule Želenskiego: „Máme právo žádati, aby [režisér] dal dílu sílu své umělecké potence, dal mu ducha svého, dal mu chleba jeho života - svéráznost" (Lukavský 1909: 376). W przeciwieństwie do swojego poprzednika nie wspomina natomiast o zależności spektaklu od wskazówek zawartych w dziele literackim. Ważniejsze bowiem dla niego jest inne zadanie reżysera:

Žádné vyšívání, ani malování netvoří ještě režii. Od té chceme, aby dala dílu duši, opojnost radostného rozmachu života, zákonný rhytmus tonu a pohybu, racovní karakter, skutečné lidi, s jejich starostmi a smutky, v jejich prostředí, u jejich bydlišt' a na jejich lučinách, pod jejich nebem. Chceme slyšet jejich mateřštinu, jejich písně, znát jejich temperament, abychom jim rozuměli a s nimi cítili (Lukavský 1909: 376).

Teatr ma być żywy dzięki naśladowaniu życia, a reżyser kreując iluzję rzeczywistości, ma pobudzać emocje widzów. Lukavský także proponuje zatem tylko połowiczną władzę reżysera nad tworzeniem świata na scenie, ogranicza ją bowiem do odtwarzania realnego życia. 
Obaj aktorzy teoretycy zatrzymują się w pół drogi przed oddaniem reżyserowi pełni władzy nad światem scenicznym. Istotne jest jednak, że zwracają uwagę na specyfikę dzieła teatralnego, które w przeciwieństwie do innych sztuk „,není obmezeno na ztrnulý výjev, na trvající chvíli, na pohyb jen znázorněný; ono žije opravdu, ono dýchá a pohybuje se, ono vnímá a vjemy suggestivně sdílí a vzněcuje, žije a životem svým nové žití probouzî" (Želenský 1908: 317). Podkreślają również, że to twórca inscenizacji, czy jest nim reżyser, czy aktor, daje jej życie, wkładając w nią część siebie, jak w bardzo emocjonalnych słowach opisał to Želenský: „Dnes už nikdo spravedlivý svědomitému herci-režiséru nepopře, že tvoří jako malîr, sochař, poeta, skladatel, jenže tvoří namahavěji, objětivěji, hazardněji: dává v šanc zdraví, všecko, život. A s životem jeho umírá i jeho umění, jež je jako omamující vůně, lahodná, krásná, leč prchavá" (Želenský 1908: 317).

Pod koniec swojego artykułu Lukavský wymienia dwa ważne dla historii teatru nazwiska: Stanisławski i Reinhardt. Według aktora wzorowanie się na ich twórczości przynosi szkodę czeskiej sztuce scenicznej, która powinna wytworzyć własny, oryginalny styl. Niemniej, przeglądając kolejne numery czasopisma „Divadlo” oraz wypowiedzi ówczesnych reżyserów, dostrzec można wyraźny wpływ zagranicznych koncepcji na ukształtowanie się w Czechach nowoczesnego myślenia o teatrze. Zaważyły na tym przede wszystkim koncepcje Maxa Reinhardta, a nieco później również Edwarda Gordona Craiga.

Mimo że już w numerach z 1910 roku zostaje opublikowany przekład jednego rozdziału z książki Craiga „O sztuce teatru” (Craig 1910: 381384, 406-409, 430-433, 453-458), szersze omówienia jego koncepcji na łamach czasopisma pojawiają się tylko w dwóch artykułach z 1912 i 1913 roku. Pierwszy z nich, autorstwa Oscara Bie, to przełożona z języka rosyjskiego rozprawa niemieckiego historyka sztuki na temat iluzji i stylu na scenie. Przeciwstawione w niej zostają idee Reinhardta jako przedstawiciela teatru iluzyjnego oraz Craiga - zwolennika stylowości. Niemal cały artykuł poświęcony jest pierwszemu z reżyserów, nazwisko Craiga pojawia się jedynie pod koniec rozważań. Padają tam jednak bardzo znamienne słowa, Bie przestrzega przed dążeniem artysty do wyniesienia reżysera ponad inne elementy inscenizacji, do oddania mu pełni władzy nad tworzeniem spektaklu, w którym zabraknie wówczas miejsca na słowo i na aktora (cf. Bie 1912). 
$\mathrm{Na}$ te same elementy teorii Craiga zwraca uwagę również Jan Reichmann, tłumacz kolejnego fragmentu książki angielskiego artysty (Craig 1920: 3-5). Ukazuje on jak ogromną wagę przykładał Craig do antynaturalistycznej scenografii, mającej zapobiec „,reprodukcji Natury” w teatrze, ponieważ „umění jest bohatší, intensivnější a životnější než život sám” (Reichmann 1913: 307). W tym celu także psychologiczne aktorstwo powinien zastapić symboliczny, wystylizowany gest, a z czasem ciało aktora - ten „bezużyteczny dla sztuki materiał” - można by wymienić na Nadmarionetę (Reichmann 1913: 306). Wreszcie Reichmann prezentuje Craiga koncepcję Artysty Teatru, która zmieniła myślenie o funkcji reżysera. W myśl tej idei, nieograniczony niczym inscenizator ma panować nad wszystkimi elementami widowiska teatralnego, aby zapewnić mu jedność, harmonię i niepowtarzalny styl.

Zdecydowanie więcej uwagi poświęca się drugiemu z reformatorów teatru - Maxowi Reinhardtowi. Jedną z przyczyn słabszej obecności może być to, że czescy reżyserzy i krytycy mieli możliwość obejrzenia jego inscenizacji, a zatem doświadczyli przełożenia jego koncepcji na praktykę teatralną. Dlatego też większość wypowiedzi pojawiających się na łamach „Divadla” stanowią opisy spektakli Reinhardta. Drugim prawdopodobnym powodem jest fakt, że jego koncepcje wydawały się mniej rewolucyjne. $\mathrm{W}$ artykułach analizujących teorie niemieckiego reżysera pojawiają się przede wszystkim informacje o innowacyjnym podejściu do scenografii, która ma być tworzona oddzielnie dla każdego przedstawienia. Docenia się również jego wkład $\mathrm{w}$ nowoczesne myślenie o teatrze $\mathrm{w}$ tym sensie, że dzięki niemu przestano mówić tylko o występach aktorskich albo o dziele literackim, a zaczęto interesować się samą inscenizacją. Mimo wszystko teatrem Reinhardta rządzi, nadal pożądana, zasada iluzji, a zadanie reżysera polega na tym, ,aby každému dílu zajistil podmínky, které sám autor pro ně položil" (Hofmanová 1911: 440).

Powyższy zarys powszechnie znanych koncepcji reformatorów teatru z początku XX wieku wydaje się konieczny ze względu na uświadomienie sobie, jakie elementy ich koncepcji zostały wówczas dostrzeżone, jak je rozumiano i w jakim stopniu zaważyły na zmianach $\mathrm{w}$ czeskim myśleniu o sztuce teatralnej, a przede wszystkim o funkcji reżysera. Wpływu Reinhardta należy upatrywać głównie w dostrzeżeniu, że inscenizacja jest dziełem autonomicznym, które, choć oparte na dziele literackim, ma własne 
środki wyrazu, a świat tworzony na scenie rządzi się specyficznymi prawami. Bardziej rewolucyjne koncepcje Craiga niewaţpliwie natomiast ukształtowały sposób myślenia o reżyserze jako o kreatorze i władcy owego scenicznego świata. Nie naśladując Natury, stwarza on zupełnie nową, poddaną sobie rzeczywistość.

$*$

Obie teorie wpłynęły zasadniczo na twórczość najwybitniejszego czeskiego reżysera tamtego okresu - Karla Hugo Hilara. On sam zresztą napisał artykuł, w którym analizuje osiagnięcia Reinhardta, doceniając przede wszystkim jego wkład w nowoczesne rozumienie reżyserii. Napisany w 1911 roku, a więc w momencie rozpoczęcia artystycznej działalności Hilara w Mětským divadle na Královských Vinohradech, tekst Pro Reinhardta jest jednocześnie wyrazem jego własnych przekonań dotyczących pozycji i funkcji reżysera, których nie zmienił przez całą swoją karierę artystyczną:

Režisérem (...) [je] ten, kdo v sebe pojav celou složitost díla, souhrn básníkových úmyslů, výsledků, vůlí i činů, básníkův plynulý sen, předvede vše to v pevné jednotě souhrnného dojmu, kterému koneckonců podřízeno je vše, nejen nábytek, dekorace, herci, ale i sám básnikův text, který musí ustoupiti všude tam, kde ohrožuje vnitřní jednotu dramatu (Hilar 2002: 165-166).

Nie tylko zatem reżyser ma prawo ingerować $\mathrm{w}$ tekst, ale w porównaniu z poprzednio cytowanymi koncepcjami posiada znacznie szerzej rozumianą moc twórczą. Za pomocą spójnej, wszechogarniającej wizji kreuje na scenie „vyšší realitu”, w której „každý výraz, posun, slovo má nutně dvojí polaritu, zmnožený význam, stupňovanou intenzitu" (Hilar 2002: 169). Teatr bowiem nie ma być obrazem ani zwierciadłem życia - jego zadaniem jest powoływać „,nové formý života (...). Jako by [divadlo] prostředkovalo přechod umělecké formy v hmotný život" (Hilar 2002: 73). Boska moc reżysera nie tylko stwarza na scenie nowe życie, czy wręcz „nový vesmír”, ale może je również przywrócić martwym dziełom literackim - utworom dawnym bądź tym, które nie doczekały się jeszcze wystawienia w teatrze. Wówczas reżyser wstępuje do nich ,jako živý, obnovující proud, který 
vnuká život celému svému nehybnému okrsku” i odnawia „vnitřní jednotu díla" (Hilar 2002: 164).

Sposób, w jaki wykreowany na scenie świat oddziałuje na widza, jest według Hilara niemożliwy do opisania, ponieważ zawiera w sobie coś magicznego, niepojętego, co zaistnieje dopiero, gdy reżyser nada dziełu jedność i niepowtarzalny styl, czyli:

něco vyššího, spontánního a v básnickém smyslu plynulého a vágního, co podobno vytržení tvoří vyšší pravdu představení, co propůjčuje mu sugestivní moc (...), co propůjčuje divadlu onu sugestivní sílu, v níž herec přestává býti hercem, kulisa kulisou, divák divákem, ale v níž vše to splyne v jeden cit, cit dramatického vytržení, v němž zúčastnění zapomenou své každodenní existence a okoušejí vyššího, to jest uměleckého štěstí (Hilar 2002: 332).

Styl ten powinien jednocześnie oddawać ducha czasu. Oznacza to, że reżyser nie może opierać się tylko na tradycji i konwencjach, wręcz przeciwnie, musi być wrażliwy na wszelkie zmiany zachodzące w sposobie myślenia i odczuwania świata, a przede wszystkim na ,nový světový názor doby", którego z pewnością nie może zrozumieć i przedstawić teatr oparty na starej estetyce. Zadaniem reżysera jest zatem skupić całą swą twórczą energię na odrzuceniu „,balastu těchto starých režijních zvyklostí a předsudků" (Hilar 2002: 333) i wytworzeniu nowych środków wyrazu. Jeśli bowiem ma być przywódcą i bojownikiem o ambitny program artystyczny teatru, „musí dovésti státi nad časem, nad chvilkovou módou, nad senzací, musí dovésti za jistých okolností jíti proti době, aby mohl jíti před nî" (Hilar 2002: 209). Parafrazując tytuł jednej z książek Hilara, prawdziwy reżyser, walczy zarówno „proti včerejšku”, jak i „,o zítřek”"

Jednocześnie umiejętność rozpoznawania dominujących prądów myślowych i emocjonalnych, ale także tego, co dopiero nadchodzi, czyni z reżysera niezbędnego współpracownika poety. To bowiem, co jeden artysta przedstawia w dziele literackim subiektywnie, za pomocą symboli i obrazów, drugi materializuje, ucieleśnia i obiektywizuje. Innymi słowy: „býti režisérem, tot' schopnost býti básníkem, který na rozdíl onoho, jenž zážitky činí pomyslnými, dané pomysly činí skutečnostmi. (...) Režisér, tot' onen básník, který ze symbolů činí viditelný svět” (Hilar 2002: 331).

\footnotetext{
${ }^{1}$ Jedna z książek Hilara wydana w 1925 roku, zawierająca artykuły dotyczące teatru, nosi tytuł Boje proti včerejšku.
} 
Wywiedzione z teorii i praktyki Reinhardta przekonanie, że posiadający moc kreacji reżyser jest najważniejszą instancją w nowoczesnym teatrze, wiąże się z oddaniem mu pełni władzy nad inscenizacją. W swoich pierwszych artykułach Hilar nazywa reżysera „,aristokratyckým suverénem, kterému věrně a oddaně musí sloužiti právě tak divadelní mistr jako hudebník, divadelní malîr a herec" (Hilar 2002: 166). Powinien w związku z tym dysponować określonymi, rozlicznymi talentami:

Vida vše malîrský, slyše vše hudebnicky, vytvářeje vše plasticky a rozvíjeje vše dramaticky, tento režisér, jenž jest suverénem dramatu, tvưrce a kritik v jedné osobě, znamená vlastního tlumočníka díla, povyšovatele každé relativní práce k absolutnímu životu, byt' jen okamžitému, jehož se dociluje v plném uměleckém dojmu, v dokonalém vnímání krásy (Hilar 2002: 166).

Po prawie dwudziestu latach pracy artystycznej Hilar dostrzega w funkcji reżysera (a właściwie w samym sobie) jeszcze większą władzę - dyktatorska. Według niego cały teatr jest tyranią, dlatego musi mu przewodzić silna osobowość artystyczna, której głównym zadaniem jest zapewnienie, by „ansámbl dospěl maxima své umělecké výkonnosti”. Dokonać może tego tylko ,umělecká osobnost typicky, umělecky výrazná, která odpovídá uměleckým potencím ansámblu, je shrnuje, stupňuje a uplatňuje" (Hilar 2002: 385). Taki był według niego zarówno Reinhardt, Craig, Stanisławski, jak i i kilku innych reformatorów teatru. Choć wiele dzieliło ich koncepcje nowoczesnej sztuki, wspólny był im ,vůdčí temperament a jednotící osobnost" (Hilar 2002: 375).

Niewątpliwie w gronie przywódczych, rewolucyjnych temperamentów widział Hilar również siebie. W napisanym w 1932 roku podsumowaniu kilkuletniej pracy w Divadle na Vinohradech wymienia dziesięć swoich spektakli, które uznaje za doskonałe przykłady awangardowego teatru z trzech głównych powodów: wspomnianego wyżej dążenia do wyrażenia ówczesnego światopoglądu, zupełnie nowego sproblematyzowania przestrzeni scenicznej oraz odmiennego sposobu gry aktorskiej (Hilar 1989: 135-139). Większość artykułów Hilara napisanych po 1910 roku służyła zresztą jako odpowiedź na niezrozumienie ze strony krytyki oraz na niezadowolenie aktorów zarzucających mu despotyczny do nich stosunek, ograniczający ich kreatywność, a także wycieńczający sposób pracy. 
W swoich publikacjach starał się zatem tłumaczyć, że nowoczesny teatr wymaga zupełnie nowych środków wyrazu, które musi przyswoić także aktor. Jednym z elementów dotychczasowej praktyki teatralnej, z którą Hilar uporczywie walczył, był manieryzm aktorów i ich gwiazdorstwo. W przedstawieniu bowiem opartym na jedności i harmonii wszystkich elementów nie było miejsca na solowe popisy. Osiaggnięcie celu, czyli wzruszenie widza, wstrzą́nięcie jego intelektem, sercem i zmysłami, wymagało działania kolektywnego (Závodský 1979: 47).

W związku z tym Hilar wymagał od aktorów pokory i zdolności podporządkowania się woli reżysera. Nie przychodziło to łatwo artystom grającym od lat według wyuczonych konwencji, tym bardziej że Hilar, przygotowując nowy spektakl, przychodził zawsze z gotową wizją, opracowaną w najmniejszych szczególach spisanych w opasłym egzemplarzu reżyserskim. Przypominający „dokonale vypracovanou partituru” wypełniony był „plány a scenografickými záznamy, dynamickými znaménky, poznámkami o rozestavení a nástupech herců, o světlech, o prýzvucích, tempu a intonaci, o gestech, obratech, přechodech, pósách atd." (Rutte 1936: 151). Reżyser jako wszechstronny artysta i jako główny twórca scenicznej rzeczywistości zarządzał bowiem wszystkimi rodzajami sztuk składającymi się na jednolite widowisko. Księga pełna zapisków służyła Hilarowi także jako broń w walce o własną wizję przedstawienia, zwłaszcza w okresie, gdy po wielu sukcesach w Divadle na Vinohradech został zaproszony do pracy w Národním Divadle. Porzucając młody zespół, który kształtował przez kilka lat, znalazł się nagle w przestrzeni rządzonej przez największe gwiazdy czeskiego teatru, niechętne zmianom swoich przyzwyczajeń, a tym bardziej własnego statusu. Praca na narodowej scenie wiązała się z licznymi konfliktami między Hilarem a aktorami. Nowy reżyser chciał panować nie tylko nad ruchem scenicznym i rozstawieniem postaci w przestrzeni. Kontrolował również ich intonację, ekspresję, tempo i rytm słów (Burian 1982: 61 i 70). Najtrudniej jednak aktorzy znosili fakt, że Hilar niejednokrotnie pokazywał, jak mają zagrać konkretną scenę, a ponadto wymagał nieznanej im dotąd ciężkiej pracy. Nie wyobrażał bowiem sobie, że każdy solista pracowałby nad rolą osobno, bez względu na kreacje pozostałych, żądał więc, by na każdej próbie obecni byli wszyscy aktorzy, a ponadto równie dużo uwagi poświęcał mniej doświadczonym członkom zespołu odgrywa- 
jącym poślednie role. Wreszcie, wielokrotnie wymagał od artystów działań wykraczających poza możliwości ludzkiego ciała, a swoje wskazówki podawał w sposób niejednoznaczny, używając metafor: „udělejte takové červené gesto” albo „zamávejte bradou” (Tetauer 1947: 74). Najczęściej jednak prowokował aktorów, nie wahał się „najít jakoukoli soukromou chybu, dotknout se kterékoliv nejtajnější hercovy bolesti, jen aby jej vyrval z jeho rovnováhy a vyštval jej na královský hon za rolî" (Frejka 1936: 297). Wybitny czeski historyk teatru, František Černý, dostrzegł w sposobie pracy Hilara inspirację koncepcją Craiga:

Hilarovým - podobně jako Craigovým - ideálem herce byla loutka. Toto tvrzení nelze chápat pejorativně. Režisér, který chtěl na scéně vytvářet zcela novou realitu, proti níž se bouřily přirozené prostředky herců, mohl svůj záměr realizovat nejúplněji právě jen s materiálem - nelidským. Hilar by se jistě býval cítil št’astný, kdyby mohl být Adamem Stvořitelem ze hry bratří Čapků, kterému bylo dovoleno z hmoty podle jeho představ hníst člověka na scěně (Černý 1968: 18).

Mimo że aktorzy nazywali Hilara dyktatorem, tyranem albo despota, liczni dostrzegli także, jak wiele się dzięki niemu nauczyli. Ponadto, krytyka sposobu pracy i żal wobec reżysera imperialisty ${ }^{2}$ pojawiają się w wypowiedziach jego zespołu na przemian ze wspomnieniami sytuacji, w których Hilar czerpał inspirację z pomysłów aktorów, a także często uznawał je za lepsze od własnych i włączał do spójnej wizji inscenizacji (Živný 1989: 101-117).

*

Najważniejszym wkładem Hilara w rozwój czeskiego teatru było rozwinięcie teorii reżyserii. Na kilka lat przed nim artyści uświadomili sobie, że pewne zmiany są konieczne, a reżyser powinien mieć większy wkład $w$ proces tworzenia inscenizacji. Hilar jednak jako pierwszy uznał tę władzę za niepodzielna, nadając jej boską moc kreacji życia na scenie. Co więcej, swoje koncepcje wcielił w życie i stworzył wiele innowacyjnych inscenizacji, które pozwoliły jego współczesnym nazwać go geniuszem,

\footnotetext{
${ }^{2}$ W ten sposób określił Hilara Frank Tetauer, tytułując jeden z podrozdziałów artykułu poświęconego jego twórczości Režisérský imperialism.
} 
bojownikiem, a nawet „Bohem posvěceným umělcem” (Sutnar (red.) 1935: 3-9). Dlatego, mimo że część historyków teatru uważa inaczej ${ }^{3}$, w niniejszym artykule Hilar został przedstawiony jako pierwszy czeski nowoczesny reżyser.

\section{Literatura}

Bie O., 1912, Iluse a styl na scéně, przeł. O. Grün, J. Reichmann, „Divadlo” XVIII, s. 131-133, 158-160, 204-206.

Burian J.M., 1982, K.H. Hilar and the Early Twentieth-Century Czech Theatre, „Theatre Journal" nr 1, s. 55-76.

Černý F., 1968, Hiarovy expresionistické režijní výboje a čeští herci, w: Význam inscenační tvorby K.H. Hilara pro moderní české divadlo, red. J. Hilmera, Praha, s. $14-20$.

Craig E.G., 1910, Divadelní umění, przeł. V.V. Štech, „Divadlo” XV, s. 381-384, 406409, 430-433, 453-458.

Craig E.G., 1920, Herec, przeł. J. Reichmann, „Divadlo” XX, s. 3-5.

„Divadlo”, 1905, XXI.

Frejka J., 1936, Hilar v práci, w: K.H. Hilar. Čtvrt století české činohry, red. M. Rutte, Praha, s. 292-301.

Hilar K.H., 1989, Mých deset avantgardních představení na Mětském divadle, „Theatralia VII. K výročí narození K.H. Hilara” nr VII, s. 135-139.

Hilar K.H., 2002, O divadle, wybór i oprac. E. Šormová, Praha.

Hofmanová M., 1911, Otázky moderního divadla, ,Divadlo” XVII, s. 439-442.

Lukavský J., 1909, Problem české režie, „Divadlo” XIII, s. 375-377.

Obst M., Scherl A., 1962, K dějinám české divadelní avantgardy, Praha.

Reichmann J., 1913, Edward Gordon Craig, „Divadlo” XXI, s. 289-291, 305-308.

\footnotetext{
${ }^{3}$ Jedni chętnie to miano nadaliby Jaroslavovi Kvapilovi, który zaczął pracę w teatrze w 1898 roku. On również walczył o nadanie reżyserowi rangi artysty, zapoczątkował też nowe myślenie o scenografii i współpracy reżysera z pisarzem. Nie udało mu się jednak przezwyciężyć gwiazdorstwa aktorów, a jego teatr nie odpowiadał na pytania nowej rzeczywistości w takim stopniu, jak uczynił to Hilar, który „divadlo zapjal do životního citu nové doby, (...) zdivadelnil a učinil (...) aktuální ve smyslu uměleckém, filosofickém i mravním" (Rutte 1936: 144). Inni historycy natomiast uważają, że pierwszym nowoczesnym reżyserem był Jindřich Honzl (w teatrze od 1926 roku), ponieważ według nich Hilar, pracujący na wielkiej scenie, nie mógł urzeczywistnić wszystkich swoich koncepcji (Obst, Scherl 1962: 90).
} 
Rutte M., 1936, K.H. Hilar. Člověk a dílo, w: K.H. Hilar. Čtvrt století české činohry, red. M. Rutte, Praha, s. 7-158.

Sutnar L. (red.), 1935, Za šéfem činohry Národního divadla v Praze Dr. K.H. Hilarem, Praha.

Tetauer F., 1947, Sedmero zástav, Praha.

Závodský A., 1979, Hilarova filozofie režie, „Sborník prací filosofické fakulty Brněnské univerzity" nr 25-26, s. 37-61.

Želenský K., 1907-1908, O režisérství, „Divadlo” X, s. 4-6, 34-36, 64-66, 114-117, 162-164.

Želenský K., 1908, O režisérství, „Divadlo” XI, s. 316-319, 340-345.

Živný V., 1989, Herci o Hilarovi, „Theatralia VII. K výročí narození K.H. Hilara” nr VII, s. 101-117. 
